Jurnal Health Sains: p-ISSN : 2723-4339 e-ISSN : 2548-1398

Vol. 2, No. 1, Januari 2021

\title{
STUDI LITERATUR DETERMINAN PERILAKU PENCEGAHAN PELECEHAN SEKSUAL PADA REMAJA
}

\author{
Hayu Ulfaningrum, Rizki Fitryasari dan Eka Misbahatul Mar'ah \\ Universitas Airlangga Surabaya, Jawa Timur, Indonesia \\ Email: uhayyu@gmail.com, rizki-f-p-k@fkp.unair.ac.id dan eka.m.has@ fkp.unair.ac.id
}

\begin{tabular}{ll}
\hline ARTIKEL INFO & ABSTRACT \\
\hline Tanggal diterima: 5 Februari & Search for journals or articles using Scopus, Sciencedirect, \\
2021 & and CINAHL database. The Joanna Briggs Institute (JBI) \\
Tanggal revisi: 15 Februari & Critical Appraisal and CRAAP test (Currency, Relevance, \\
2021 & Authority, Accuracy and Purpose) were used in the \\
Tanggal yang diterima: 25 & assessment of article quality. The inclusion and exclusion \\
Februari 2021 & criteria in this literature study used the PICOS framework. \\
\hline Keywords: & Inclusion criteria in this literature study include \\
Prevention Behavio;, Sexual & adolescents aged 10-18 years, factors of knowledge, \\
Harassment; Adolescents & attitudes, values, sexual education, family, peers and \\
& teachers using a randomized controlled trial, cross- \\
& sectional study design, mixed-method design, grounded- \\
& theory design, school-based survey, retrospective study, \\
& qualitative study, quasi-experimental design with English- \\
& language articles and published years from 2016 to 2020. \\
& The number of articles obtained based on eligibility for \\
& inclusion and exclusion criteria was 14 articles. Factors \\
& related to sexual harassment prevention behaviours among \\
& adolescents in developed and developing countries are \\
& knowledge and attitudes, provision of sexual education, \\
& role of health workers, family factors, support from \\
& teachers, school staff and peers. Efforts to prevent sexual \\
& harassment in adolescents have been carried out a lot, but \\
& it is necessary to have clear involvement and direction for \\
health workers and there is a need for clear legal & protection for perpetrators of sexual harassment so that \\
they are not increasingly rampant and are considered & normalfor the community.
\end{tabular}

\begin{abstract}
ABSTRAK
Pencarian jurnal atau artikel menggunakan database Scopus, Sciencedirect, CINAHL. The Joanna Briggs Institute (JBI) Critical Appraisal dan CRAAP test (Currency, Relevance, Authority, Accuracy and Purpose) digunakan dalam penilaian kualitas artikel. Kriteria inklusi dan eksklusi dalam studi literatur ini menggunakan format PICOS framework. Kriteria inklusi dalam studi literature ini antara lain remaja dengan usia $10-18$ tahun, faktor pengetahuan, sikap, nilai, pendidikan seksual, keluarga,

teman sebaya dan guru menggunakan desain studi randomized controlled trial, cross-sectional study, mixedmethod design, grounded-theory design, school-based
\end{abstract}

Kata Kunci:

Perilaku Pencegahan, Pelecehan Seksual, Remaja 
survey, retrospective study, qualitative study, quasiexperimental design dengan artikel berbahasa inggris dan tahun terbit 2016 - 2020. Jumlah artikel yang didapatkan berdasarkan kelayakan terhadap kriteria inklusi dan eksklusi sebanyak 14 artikel. Hasil: Faktor yang berhubungan dengan perilaku pencegahan pelecehan seksual pada remaja di negara maju dan berkembang yaitu pengetahuan dan sikap, pemberian pendidikan seksual, peran petugas kesehatan, faktor keluarga, dukungan guru, staff sekolah dan teman sebaya. Upaya pencegahan pelecehan seksual pada remaja telah banyak dilakukan, namun diperlukan adanya keterlibatan dan arahan yang jelas bagi petugas kesehatan serta perlu adanya perlindungan hukum secara jelas bagi para pelaku pelecehan seksual agar tidak semakin merajalela dan dianggap hal yang biasa bagi masyarakat.

Coresponden Author:

Email: uhayyu@gmail.com Artikel dengan akses terbuka dibawah lisensi

\section{Pendahuluan}

Fenomena pelecehan seksual semakin meningkat dan menjadi permasalahan yang serius di berbagai negara. Pelecehan seksual dapat dialami oleh perempuan maupun lakilaki, tidak memandang usia, dan dapat terjadi di sekolah, masyarakat maupun ruang publik (Yudha et al., 2020).

Pelecehan seksual merupakan bentuk perilaku yang mengarah kepada hal-hal seksual yang dilakukan secara sepihak dan perilaku yang tidak diharapkan oleh orang yang menjadi sasarannya dan menimbulkan reaksi negatif seperti malu, marah, benci, tersinggung dan sebagainya (Firman et al., 2018). Pelecehan seksual yang terjadi di negara maju dan berkembang memiliki karakteristik yang sama dan dapat diklasifikasikan menjadi pelecehan seksual bersifat visual (misalnya tatapan penuh nafsu, tatapan mengancam korban, gerak gerik yang bersifat seksual), pelecehan seksual verbal (misalnya siulan, gossip, gurauan yang mengarah pada seksual dan pernyataan yang bersifat mengancam) dan pelecehan seksual terhadap fisik (misalnya sentuhan, mencubit, menepuk, menyenggol dengan sengaja, meremas dan mendekatkan diri tanpa diinginkan) (Yudha et al., 2020).

Pelecehan seksual dapat menimbulkan dampak fisik, psikologis hingga dampak sosial. Berdasarkan penelitian World Health Organization (Organization, 2013) yang dilakukan di berbagai negara menunjukkan pelecehan seksual terjadi di sekolah, universitas dan tempat kerja yang dilakukan oleh orang terdekat korban seperti teman, guru maupun pimpinan kerja (Rusyidi et al., 2019). Berdasarkan data United Nations Development Fund For Women (UNIFEM), pelecehan seksual di Eropa sebanyak $55 \%$ perempuan pernah mengalami setidaknya satu bentuk pelecehan seksual sejak berusia 15 tahun dan 21\% melaporkannya dalam 12 bulan sebelumnya. Kejadian di Negara Amerika Serikat, sebanyak $80 \%$ remaja perempuan dengan usia 12 - 16 tahun mengaku pernah mengalami pelecehan seksual di sekolah (Women, 2014).

Jurnal Health Sains Vol. 2, No. 2, Februari 2021 
Badan FRA-Uni Eropa untuk hak - hak fundamental (Shaharanee \& Jamil, 2014) melaporkan bahwa 83 - 102 juta perempuan $(45 \%-55 \%)$ di 28 negara anggota UE mengalami pelecehan seksual sejak usia 15 tahun. Tingkat prevalensi tertinggi ditemukan pada Negara Denmark sebanyak 37 persen, Swedia sebanyak 32 persen, Belanda sebanyak 32 persen, Perancis sebanyak 30 persen, Belgia sebanyak 30 persen, Slovakia sebanyak 29 persen dan Inggris Raya sebanyak 25 persen (Chester et al., 2018). Prevalensi pelecehan seksual di Indonesia mencapai 520 kasus (Perempuan \& Tahunan, 2020). Sementara itu, menurut survei nasional di ruang publik tahun 2018 kejadian pelecehan seksual di Indonesia pada perempuan sebesar 64 persen, laki-laki 11 persen, dan transeksual sebanyak 69 persen (Kopetz et al., 2019).

Hal yang paling penting dalam pencegahan pelecehan seksual adalah mengenal hak pribadi dan hak orang lain serta memahami bahwa hak seseorang adalah hal yang harus dihormati dan dihargai. Adanya pemahaman akan hak-hak pribadi dan orang lain, seseorang akan dapat menjaga dan menahan diri dari tindakan pelecehan seksual terhadap orang lain, sekaligus juga mengetahui bahwa dirinya berhak untuk bebas dari pelecehan seksual yang dilakukan orang lain (Armendariz et al., 2020). Perilaku pencegahan pelecehan seksual dapat dipengaruhi oleh factor pengetahuan, persepsi, pemberian pendidikan seksual, keterlibatan guru dalam proses pembelajaran di sekolah dan cara pola asuh orang tua (Mohd Hanim et al., 2014). Namun dalam penelitian ini belum membahas tentang faktor-faktor yang mempengaruhi pelecehan seksual pada remaja di negara berkembang dan negara maju. Oleh karena itu peneliti tertarik untuk menyusun literature review tentang faktor yang mempengaruhi perilaku pencegahan pelecehan seksual pada remaja di negara maju dan berkembang.

\section{Metode Penelitian}

Pencarian literatur dilakukan pada bulan Mei - Juli 2020 dengan menggunakan data sekunder. Perumusan pertanyaan penelitian menggunakan PICOS (Population/Problem, interest/Intervention, Comparison, Outcome dan Study design) dan menggunakan kata kunci yang disesuaikan dengan Medical Subject Heading (MeSH) yaitu Risk factors OR Causality AND Sexual Harassment OR Sexual abuse AND Behavior OR attitude OR Values AND Adolescents OR Teenagers OR Peer Group AND Knowledge OR Sex Education AND Parents AND Teacher AND Health Professionals OR Nurse, public health practice.

Pencarian artikel didapatkan dari database Scopus, Sciencedirect, dan CINAHL menggunakan kata kunci yang dipilih dan dipublikasikan 5 tahun terakhir yaitu pada rentang tahun 2016 - 2020 dengan artikel berbahasa inggris, dapat diakses secara fulltext dan open access.

Artikel yang ditemukan sebanyak 6.820, Kemudian dilakukan seleksi duplikat menggunakan mendeley sebanyak 888 artikel. Tahap berikutnya yakni melakukan screening terhadap judul yang tidak relevan sebanyak 749 artikel, selanjutnya melakukan screening pada abstrak yang tidak relevan sebanyak 139 artikel. Pengeliminasian dilakukan pada artikel yang tidak memenuhi kriteria inklusi dimana populasi bukan remaja sebanyak 29 artikel, intervensi yang tidak relevan dengan perilaku pencegahan pelecehan seksual sebanyak 54 artikel, outcome yang tidak relevan dengan perilaku pencegahan pelecehan seksual sebanyak 28 artikel dan desain studi yang tidak sesuai dengan kriteria inklusi sebanyak 14 artikel sehingga artikel yang digunakan dalam literature review ini sebanyak 14 artikel. 
Penilaian kualitas dalam studi literature review ini menggunakan The Joanna Briggs Institute (JBI) Critical Appraisal dan CRAAP test (Currency, Relevance, Authority, Accuracy and Purpose)

\section{Hasil Penelitian}

Hasil pencarian artikel didapatkan jenis pelecehan seksual dan faktor-faktor yang berhubungan dengan perilaku pencegahan pelecehan seksual pada remaja.

1. Jenis Pelecehan Seksual

Jenis pelecehan seksual yang seringkali dialami oleh remaja di negara maju dan berkembang memiliki karakteristik yang sama meliputi pelecehan seksual verbal, pelecehan seksual fisik, dan serangan seksual. Pelecehan seksual verbal seperti bahasa homofobik (misalnya, remaja dijuluki "gay", "homo"), komentar seksual yang tidak diinginkan, menyebarkan rumor seksual, menampilkan atau membagikan gambar, foto, ilustrasi, pesan atau catatan dan menulis sesuatu di dinding kamar mandi (Karmakar et al., 2020) Pelecehan seksual fisik seperti menyentuh bagian vital (pantat, payudara alat kelamin), menarik pakaian lepas / turun (terengahengah) (Espelage et al., 2016). Serangan seksual seperti dipaksa mencium atau melakukan sesuatu yang bersifat seksual (Clasen et al., 2018).

2. Pengetahuan dan Sikap

Faktor-faktor yang mempengaruhi pengetahuan dan sikap remaja di negara maju dan berkembang dipengaruhi oleh jenis kelamin, usia dan lokasi tempat tinggal. Remaja perempuan memiliki pengetahuan yang lebih baik mengenai pelecehan seksual dibandingkan dengan remaja pria. Adanya pertambahan usia dapat meningkatkan pengetahuan dan pengalaman dalam pencegahan pelecehan seksual pada remaja (Wangamati et al., 2018). Remaja yang tinggal di perkotaan memiliki pengetahuan yang baik dalam pencegahan pelecehan seksual jika dibandingkan dengan daerah perkotaan atau pegunungan (Achora et al., 2018). Semakin tinggi pengetahuan remaja dalam pencegahan pelecehan seksual maka resiko terjadinya pelecehan seksual semakin berkurang bahkan perilaku pelecehan tersebut tidak terjadi (Tran et al., 2019).

3. Pendidikan Seksual

Pendidikan seksual penting untuk diterapkan di sekolah baik negara maju dan berkembang. Pemberian pendidikan seksual dapat meningkatkan pengetahuan, harga diri, membangun self-efficacy dan menanamkan serta memperkuat gender dan norma sosial yang positif sehingga dapat mencegah perilaku pelecehan seksual (Wangamati et al., 2018). Program pendidikan seksual yang berhasil membutuhkan mekanisme formal yang ditetapkan oleh otoritas pendidikan untuk mengawasi pelaksanaannya (Achora et al., 2018)

4. Peran Petugas Kesehatan

Pemberian pendidikan kesehatan yang diberikan oleh petugas kesehatan secara partisipatif dan melakukan pendekatan informal kepada remaja memiliki dampak positif yang signifikan terhadap fakta tentang seks dan seksualitas, identifikasi masalah kesehatan seksual remaja dan mempromosikan partisipasi aktif remaja (Acharya et al., 2017). Pendidikan kesehatan yang dipimpin oleh petugas kesehatan dapat meningkatkan pengetahuan dan praktik dalam pencegahan dan perlindungan remaja dari pelecehan seksual (El Guindi, 2018).

5. Keluarga

Faktor keluarga yang berhubungan dengan pencegahan perilaku pelecehan seksual meliputi, remaja yang tinggal bersama orang tua, faktor ekonomi, dan keterlibatan orangtua. Remaja yang tinggal serumah dengan orangtua akan meningkatkan bimbingan, pengawasan 
dan perlindungan orangtua terhadap remaja sehingga dapat mengurangi terjadinya perilaku pelecehan seksual (Nlewem \& Amodu, 2017). Karakteristik keluarga sosio-demografis yang kurang menguntungkan dapat mengakibatkan remaja seringkali melakukan perilaku berisiko, memiliki koping yang buruk dan gejala emosional yang membuat remaja rentan terhadap pelecehan seksual (Kaltiala-Heino et al., 2016). Keterlibatan orang tua dalam mengamati perkembangan seksual berperan penting dalam meminimalisir perilaku pelecehan seksual. Adanya keterlibatan orang tua dalam kehidupan remaja dapat membuat remaja mengambil keputusan seksualnya dengan tepat (de Lijster et al., 2019).

6. Dukungan Guru, Staff Sekolah dan Teman Sebaya

Bentuk pencegahan pelecehan seksual pada remaja yaitu melakukan penerapan sekolah berbasis interaktif. Sekolah berbasis interaktif memiliki pendekatan perilaku kognitif, berfokus pada keterampilan sosial dan kompetensi sosial (van Lieshout et al., 2019). Penerapan sekolah berbasis interaktif melaporkan norma sosial yang lebih positif untuk menolak pelecehan seksual, self-efficacy yang lebih tinggi sehubungan dengan berhasil menolak perilaku pelecehan seksual, dan berkurangnya niat untuk melakukan pelecehan seksual (de Lijster et al., 2019).

Dukungan dari teman sebaya dapat memberikan dukungan emosional dan sosial pada remaja. Semakin tinggi pengetahuan mengenai tindakan pencegahan pelecehan seksual yang dimiliki teman sebaya maka akan memberikan pengaruh terhadap remaja tersebut (Clasen et al., 2018).

\section{Pembahasan}

\section{Jenis Pelecehan Seksual}

Setelah menelusuri empat belas artikel yang direview, lebih dari 50\% artikel memaparkan jenis pelecehan seksual yang dialami remaja di negara maju dan berkembang meliputi komentar dan lelucon yang mengarah pada seksualitas seseorang, menyebarkan rumor seksual, menyentuh bagian alat vital dan masturbasi di hadapan remaja. Perempuan lebih cenderung mendapatkan komentar seksual sedangkan lelaki dikaitkan pada kejantanan mereka yang dipertanyakan dan hal tersebut bersifat homofobik (Odenbring et al., 2019). Hal tersebut diperkuat dengan hasil penelitian (Reed, 2019), menjelaskan bahwa prevalensi jenis pelecehan seksual yang seringkali terjadi pada remaja meliputi komentar, lelucon atau gerak tubuh seksual sebesar 57,2 persen. Menyentuh, memegang atau menyubit bagian tubuh secara seksual sebesar 12,6 persen dan pelaku melakukan masturbasi di hadapan remaja sebesar 3,8 persen. Lebih dari 30 persen remaja perempuan melaporkan telah mengalami dua jenis atau lebih pelecehan seksual selama 6 bulan terakhir dan pelaku pelecehan seksual sebagian besar adalah laki-laki yang tidak dikenal oleh korban sebesar 82,7 persen. Adanya prevalensi yang tinggi mengenai jenis pelecehan seksual yang seringkali terjadi pada remaja, membuat perlunya memberikan suatu pendidikan pencegahan pelecehan seksual yang melibatkan berbagai pihak seperti keluarga, sekolah, teman sebaya, pemangku kepentingan umum dan pembuat kebijakan.

2. Faktor yang Berhubungan dengan Perilaku Pencegahan Pelecehan Seksual pada Remaja di Negara Maju dan Negara Berkembang 
Pelecehan seksual yang tidak ditangani dengan segera akan mempengaruhi kehidupan remaja selanjutnya. Faktor - faktor yang berhubungan dengan perilaku pencegahan pelecehan seksual pada remaja di negara maju dan berkembang meliputi adanya pengetahuan dan sikap, pemberian pendidikan seksual, peran petugas kesehatan, faktor keluarga, dukungan guru, staff sekolah dan teman sebaya. Faktor tersebut dapat dijelaskan sebagaimana berikut:

a. Hubungan Faktor Pengetahuan dan Sikap dengan Pencegahan Pelecehan Seksual pada Remaja

Pengetahuan dan sikap remaja dapat dipengaruhi oleh jenis kelamin, usia dan lokasi tempat tinggal. Hal tersebut diperkuat dengan hasil penelitian di negara berkembang yakni remaja perempuan memiliki pengetahuan yang baik mengenai pelecehan seksual dibandingkan dengan remaja laki-laki dikarenakan masyarakat memiliki persepsi bahwa korban pelecehan hanya terjadi pada perempuan. Dengan demikian, remaja perempuan lebih mendapat perhatian dari keluarga dan mendapatkan informasi mengenai seksualitas dari orang tua mereka (Do et al., 2017). Adanya pertambahan usia menyebabkan pengetahuan dalam mencegah pelecehan seksual semakin meningkat. Remaja yang tinggal di perkotaan memiliki pengetahuan yang baik mengenai pelecehan seksual bila dibandingkan dengan daerah pedesaan (Alrammah \& Ghazal, 2018). Namun, ada sedikit perbedaan pada hasil penelitian di negara maju ditemukan bahwa faktor pengetahuan dan sikap remaja dipengaruhi oleh jenis kelamin, usia dan etnis. Remaja perempuan memiliki pengetahuan yang lebih baik dibandingkan dengan remaja laki - laki terkait dengan pelecehan seksual. Usia mempengaruhi proses berfikir seorang remaja, semakin tua usia seseorang maka pengetahuan yang diperoleh semakin meningkat. Remaja dengan keturunan Eropa memiliki pengetahuan lebih baik dibandingkan dengan latar belakang etnis lain (Svensson et al., 2019). Kelompok etnis yang berbeda dalam nilai-nilai seksual mereka dikarenakan adanya pengaruh budaya, politik dan agama yang beragam pada dukungan norma, peran gender dan berakibat pada seksualitas (Safdar \& KosakowskaBerezecka, 2015).

b. Hubungan Faktor Pendidikan Seksual dengan Pencegahan Pelecehan Seksual pada Remaja

Abdullah Nashih Ulwan mengemukakan bahwasannya pendidikan seks merupakan suatu upaya dalam pengajaran, penyadaran dan penerangan mengenai masalah masalah seksual yang diberikan kepada anak sejak ia memahami masalah-masalah yang berkenaan dengan seks, naluri dan perkawinan (Madani, 2014). Pernyataan tesebut diperkuat oleh pendapat Halstead dan Reiss bahwasannya tujuan pendidikan seksual tak hanya memberikan informasi mengenai seksualitas saja, namun dapat menumbuhkan sikap, perilaku positif serta refleksi kritis mengenai pengalaman individu (Gandeswari et al., 2020). Pendidikan seksual akan mempengaruhi pola perilaku remaja yang ingin mengenal dirinya yakni organ reproduksi dan 
kematangan pada organ reproduksi yang dimilikinya (Ahmad et al., 2017). Unsur agama juga diikutsertakan di dalamnya sehingga memuat pendidikan akhlak dan moral yang dapat mengurangi perilaku pelecehan seksual pada remaja (Faswita \& Suarni, 2018). Hal tersebut membuat pendidikan seks sangat penting diberikan agar remaja dapat memproteksi dirinya sendiri dari orang yang memiliki niat yang buruk kepada mereka dan dapat memberikan pemahaman mengenai tindakan yang seharusnya boleh atau tidak boleh dilakukan (Gandeswari et al., 2020). Pemberian pendidikan seksual baik di negara maju dan berkembang telah diterapkan di lingkungan keluarga dan sekolah serta terbukti efektif dalam meningkatkan perlindungan diri remaja dan pemahaman mengenai pencegahan pelecehan seksual.

c. Hubungan Peran Petugas Kesehatan dengan Pencegahan Pelecehan Seksual pada Remaja.

$$
\text { Melakukan promosi }
$$

kesehatan, memberikan informasi mengenai tindakan yang harus dilakukan ketika seorang remaja dilecehkan (Gatuguta et al., 2019). Pemberian edukasi dilakukan melalui penyuluhan, media KIE dan pendidikan kesehatan reproduksi dalam meningkatkan pengetahuan masyarakat mengenai pelecehan seksual terutama remaja.

Pendidikan kesehatan juga dapat dilakukan menggunakan media seperti leaflet, video, slide suara, animasi dan sebagainya. Petugas kesehatan juga dapat bekerjasama dengan pihak sekolah dalam meningkatkan pelayanan kesehatan sekolah melalui peningkatan ketenagaan UKS. Adanya upaya dalam meningkatkan peran UKS diharapkan dapat mempermudah pembinaan dan pencegahan perilaku pelecehan seksual pada remaja dengan memberikan edukasi menjauhi perbuatan asusila dan kriminalitas (Linati, 2016).

d. Hubungan Faktor Keluarga dengan Pencegahan Pelecehan Seksual pada Remaja

Peran keluarga atau orangtua merupakan faktor yang paling penting dari enam faktor yang berhubungan dengan pencegahan pelecehan seksual pada remaja di negara maju dan berkembang.

Penelitian yang dilakukan oleh (Ligina et al., 2018) menyatakan bahwa Orangtua memiliki enam peran dalam mencegah pelecehan seksual yakni orangtua berperan sebagai pendorong agar remaja dapat percaya diri dan melawan tindak kejahatan, orangtua sebagai pendidik dan komunikator dalam berkomunikasi dua arah mengenai pencegahan pelecehan seksual, orangtua sebagai pengawas dan panutan seorang remaja dalam penggunaan telepon seluler dan internet yang positif serta orangtua sebagai konselor dalam berdiskusi dengan remaja mengenai masalah maupun rahasia yang dimiliki oleh remaja. Orang tua yang memiliki kesadaran tinggi dan pengetahuan mengenai pelecehan seksual lebih mampu memantau remaja tersebut dalam berinteraksi dengan lingkungan, dapat melindungi dari situasi yang berpotensi terjadinya pelecehan serta lebih mampu mengidentifikasi pelecehan secara 
tepat waktu, menanggapi pengungkapan secara tepat dan mengambil tindakan pencegahan dengan segera (Chen et al., 2019).

e. Hubungan Dukungan Guru, Staff Sekolah dan Teman Sebaya dengan Pencegahan Pelecehan Seksual pada Remaja

Berdasarkan hasil penelitian (Melgosa et al., 2020) Guru dan staff sekolah berperan penting dalam pencegahan dan identifikasi pelecehan seksual karena siswa banyak menghabiskan waktu di sekolah sehingga berpengaruh cukup kuat dalam perkembangan masa remaja.

Guru dan staff sekolah menjadi elemen sekolah yang dekat dengan siswa. Dukungan guru dapat memberikan suatu dukungan emosional seperti rasa empati, penghargaan, perhatian, kepedulian, pengarahan, bimbingan dan pengajaran langsung yang dirasakan oleh siswa (Prihastyanti \& Sawitri, 2018). Guru dan staff sekolah berpengaruh dalam membentuk sikap dan perilaku remaja, menggarisbawahi pentingnya tindakan pengamat guru yang efektif dalam pencegahan pelecehan seksual di kalangan remaja (Edwards, Rodenhizer, \& Eckstein, 2020).

Berdasarkan penelitian

(Mardiah et al., 2017) dukungan teman sebaya memiliki pengaruh yang besar dalam menurunkan perilaku pelecehan seksual pada remaja. Remaja yang memiliki pergaulan dengan teman sebaya yang mencontohkan sikap positif, memiliki perilaku yang sehat, membangun pengetahuan kesehatan seksual, mengkomunikasikan strategi pencegahan dan pengurangan resiko terhadap pelecehan seksual akan berdampak pada pengetahuan dan perilaku remaja tersebut (Layzer et al., 2017)

\section{Kesimpulan}

Hasil studi literatur ini menunjukkan jenis pelecehan seksual yang seringkali terjadi pada remaja di negara maju dan berkembang seperti komentar dan lelucon yang mengarah pada seksualitas seseorang, menyebarkan rumor seksual, menyentuh bagian alat vital dan masturbasi di hadapan remaja. Sedangkan faktor yang berhubungan dengan pencegahan pelecehan seksual pada remaja meliputi pengetahuan dan sikap, pendidikan seksual, faktor keluarga, dukungan guru, staff sekolah dan teman sebaya. Faktor pengetahuan dan sikap menjadi aspek yang sangat penting terlepas dari faktor internal yang mempengaruhi perilaku remaja. Faktor keluarga menjadi aspek yang sangat penting terlepas dari faktor eksternal yang memberikan pengawasan dan perlindungan terhadap remaja. Upaya pencegahan pelecehan seksual pada remaja telah banyak dilakukan, namun diperlukan adanya keterlibatan dan arahan yang jelas bagi petugas kesehatan serta perlu adanya perlindungan hukum secara jelas bagi para pelaku pelecehan seksual agar tidak semakin merajalela dan dianggap hal yang biasa bagi masyarakat.

\section{BIBLIOGRAFI}

Acharya, D., Thomas, M., \& Cann, R. (2017). Evaluating School-Based Sexual Health Education Programme In Nepal: An Outcome From A Randomised Controlled Trial. International Journal Of Educational Research, 82, 147-158.

Achora, S., Thupayagale-Tshweneagae, G., Akpor, O. A., \& Mashalla, Y. J. S. (2018). Perceptions Of Adolescents And 
Teachers On School-Based Sexuality Education In Rural Primary Schools In Uganda. Sexual \& Reproductive Healthcare, 17, 12-18.

Ahmad, S., Lavin, A., Purdy, S., \& Agha, Z. (2017). Unsupervised Real-Time Anomaly Detection For Streaming Data. Neurocomputing, 262, 134-147.

Alrammah, H., \& Ghazal, S. (2018). Significant Left Ventricular Outflow Tract Obstruction Secondary To Systolic Anterior Motion In A Patient Without Hypertrophic Cardiomyopathy: An Echocardiographic Study. Journal Of The Saudi Heart Association, 30(4), 336-339.

Armendariz, C. S., Purver, M., Pollak, S., Ljubešić, N., Ulčar, M., Vulić, I., \& Pilehvar, M. T. (2020). Semeval-2020 Task 3: Graded Word Similarity In Context. Proceedings Of The Fourteenth Workshop On Semantic Evaluation, 3649.

Chen, Y., Chen, X.-Y., Du, H.-T., Zhang, X., Ma, Y.-M., Chen, J.-C., Ye, J.-W., Jiang, X.-R., \& Chen, G.-Q. (2019). Chromosome Engineering Of The Tca Cycle In Halomonas Bluephagenesis For Production Of Copolymers Of 3Hydroxybutyrate And 3Hydroxyvalerate (Phbv). Metabolic Engineering, 54, 69-82.

Chester, B., Stanely, W. G., \& Geetha, T. (2018). Quick Guide To Type 2 Diabetes Self-Management Education: Creating An Interdisciplinary Diabetes Management Team. Diabetes, Metabolic Syndrome And Obesity: Targets And Therapy, 11, 641 .

Clasen, L. E., Blauert, A. B., \& Madsen, S. A. (2018). "What Will My Friends Think?" Social Consequences For Danish Victims Of Sexual Assaults In Peer Groups. Journal Of Child Sexual Abuse, 27(3), 217-236.

Jurnal Health Sains Vol. 2, No. 2, Februari 2021
De Lijster, G. P. A., Kok, G., \& Kocken, P. L. (2019). Preventing Adolescent Sexual Harassment: Evaluating The Planning Process In Two School-Based Interventions Using The Intervention Mapping Framework. Bmc Public Health, 19(1), 1-12.

Do, L. A. T., Boonmongkon, P., Paek, S. C., \& Guadamuz, T. E. (2017). 'Hu Hong'(Bad Thing): Parental Perceptions Of Teenagers' Sexuality In Urban Vietnam. Bmc Public Health, 17(1), 111.

El Guindi, F. (2018). Properties Of Kinship Structure: Transformational Dynamics Of Suckling, Adoption And Incest. And Extension In Kinship, 177.

Espelage, D. L., Hong, J. S., Rinehart, S., \& Doshi, N. (2016). Understanding Types, Locations, \& Perpetrators Of Peer-ToPeer Sexual Harassment In Us Middle Schools: A Focus On Sex, Racial, And Grade Differences. Children And Youth Services Review, 71, 174-183.

Faswita, W., \& Suarni, L. (2018). Hubungan Pendidikan Seks Dengan Perilaku Seksual Pada Remaja Putri Di Sma Negeri 4 Binjai Tahun 2017. Jumantik (Jurnal Ilmiah Penelitian Kesehatan), $3(2), 28-45$.

Firman, F., Karneli, Y., \& Hariko, R. (2018). Improving Students' Moral Logical Thinking And Preventing Violent Acts Through Group Counseling In Senior High Schools. Advanced Science Letters, 24(1), 24-26.

Gandeswari, K., Husodo, B. T., \& Shaluhiyah, Z. (2020). Faktor-Faktor Yang Mempengaruhi Perilaku Orangtua Dalam Memberikan Pendidikan Seks Usia Dini Pada Anak Pra Sekolah Di Kota Semarang. Jurnal Kesehatan Masyarakat (E-Journal), 8(3), 298-305.

Gatuguta, A., Colombini, M., Seeley, J., Soremekun, S., \& Devries, K. (2019). 
Supporting Children And Adolescents Who Have Experienced Sexual Abuse To Access Services: Community Health Workers' Experiences In Kenya. Child Abuse \& Neglect, 104244.

Kaltiala-Heino, R., Fröjd, S., \& Marttunen, M. (2016). Sexual Harassment Victimization In Adolescence: Associations With Family Background. Child Abuse \& Neglect, 56, 11-19.

Karmakar, N., Arora, S., \& Franky, S. (2020). Effectiveness Of Assertiveness Training Programme On Knowledge And Attitude Of Adolescent Girls Regarding Prevention Of Sexual Abuse.

Kopetz, S., Grothey, A., Yaeger, R., Van Cutsem, E., Desai, J., Yoshino, T., Wasan, H., Ciardiello, F., Loupakis, F., \& Hong, Y. S. (2019). Encorafenib, Binimetinib, And Cetuximab In Braf V600e-Mutated Colorectal Cancer. New England Journal Of Medicine, 381(17), 1632-1643.

Layzer, C., Rosapep, L., \& Barr, S. (2017). Student Voices: Perspectives On Peer To-Peer Sexual Health Education. Journal Of School Health, 87(7), 513523.

Ligina, N. L., Mardhiyah, A., \& Nurhidayah, I. (2018). Peran Orang Tua Dalam Pencegahan Kekerasan Seksual Pada Anak Sekolah Dasar Di Kota Bandung. Ejournal Umm, 9(2), 109-118.

Linati, P. A. (2016). Disinfeksi Cetakan Alginat Dengan Cairan Aloe Barbadensis Mill. Menggunakan Teknik Penyemprotan Terhadap Stabilitas Dimensional. Universitas Airlangga.

Madani, K. (2014). Water Management In Iran: What Is Causing The Looming Crisis? Journal of Environmental Studies And Sciences, 4(4), 315-328.

Mardiah, A., Satriana, D. P., \& Syahriati, E. (2017). Peranan Dukungan Sosial
Dalam Mencegah Kekerasan Dalam Pacaran: Studi Korelasi Pada Remaja Di Jakarta. Jurnal Psikologi Ulayat: Indonesian Journal of Indigenous Psychology, 4(1), 29-42.

Melgosa, M., Madrid, A., Alvárez, O., Lumbreras, J., Nieto, F., Parada, E., \& Perez-Beltrán, V. (2020). Sars-Cov-2 Infection In Spanish Children With Chronic Kidney Pathologies. Pediatric Nephrology, 35(8), 1521-1524.

Mohd Hanim, A. B., Chin, N. L., \& Yusof, Y. A. (2014). Physico-Chemical And Flowability Characteristics Of A New Variety Of Malaysian Sweet Potato, Vitato Flour. International Food Research Journal, 21(5).

Nlewem, C., \& Amodu, O. K. (2017). Family Characteristics And Structure As Determinants Of Sexual Abuse Among Female Secondary School Students In Nigeria: A Brief Report. Journal of Child Sexual Abuse, 26(4), 453-464.

Odenbring, Y., Johansson, T., Hammarén, N., \& Lunneblad, J. (2019). The Absent Victim: Schools' Assessment Of The "Victimization Process." Urban Education, 54(7), 1007-1028.

Organization, W. H. (2013). Global Tuberculosis Report 2013. World Health Organization.

Perempuan, K., \& Tahunan, C. (2020). Komnas Perempuan. In Retrieved From Komnasperempuan. Go. Id: Https://Www. Komnasperempuan. Go. Id/Read-News-MenemukenaliKekerasan-Dalam-Rumah-Tangga-Kdrt.

Prihastyanti, I., \& Sawitri, D. R. (2018). Hubungan Antara Dukungan Guru Dengan Efikasi Diri Akademik Pada Siswa Sma Semesta Semarang. Undip.

Reed, T. V. (2019). The Art Of Protest: Culture And Activism From The Civil Rights Movement To The Present. U Of 
Minnesota Press.

Rusyidi, B., Bintari, A., \& Wibowo, $\mathrm{H}$. (2019). Pengalaman Dan Pengetahuan Tentang Pelecehan Seksual: Studi Awal Di Kalangan Mahasiswa Perguruan Tinggi (Experience And Knowledge On Sexual Harassment: A Preliminary Study Among Indonesian University Students). Share: Social Work Journal, 9(1), 75-85.

Safdar, S., \& Kosakowska-Berezecka, N. (2015). Gender Through The Lens Of Culture. In Psychology of Gender Through The Lens Of Culture (Pp. 114). Springer.

Shaharanee, I. N. M., \& Jamil, J. (2014). Evaluation And Optimization Of Frequent Association Rule Based Classification. Asia-Pacific J. Inf. Technol. Multimed, 3(1), 1-13.

Svensson, J., Baer, N., \& Silva, T. (2019). Adolescents' Level Of Knowledge Of And Supportive Attitudes To Sexual Crime In The Swedish Context. Journal Of Sexual Aggression, 25(2), 75-89.

Tran, L. S., Pham, H.-A. T., Tran, V.-U., Tran, T.-T., Dang, A.-T. H., Le, D.-T., Nguyen, S.-L., Nguyen, N.-V., Nguyen, T.-V., \& Vo, B. T. (2019). Ultra-Deep Massively Parallel Sequencing With Unique Molecular Identifier Tagging Achieves Comparable Performance To Droplet Digital Pcr For Detection And Quantification Of Circulating Tumor Dna From Lung Cancer Patients. Plos One, 14(12), E0226193.
Van Lieshout, S., Mevissen, F. E. F., Van Breukelen, G., Jonker, M., \& Ruiter, R. A. C. (2019). Make A Move: A Comprehensive Effect Evaluation Of A Sexual Harassment Prevention Program In Dutch Residential Youth Care. Journal of Interpersonal Violence, 34(9), 1772-1800.

Wangamati, C. K., Sundby, J., \& Prince, R. J. (2018). Communities' Perceptions Of Factors Contributing To Child Sexual Abuse Vulnerability In Kenya: A Qualitative Study. Culture, Health \& Sexuality, 20(12), 1394-1408.

Women, U. N. (2014). Women And Poverty. Author. Retrieved From Http://Beijing20. Unwomen. Org/En/Infographic/Poverty.

Yudha, D. S., Trijoko, T., Eprilurahman, R., Nugraha, R., Suranto, R. D. P., Abida, F. U., Tobing, V. F., Fathiya, R. F., \& Nopitasari, S. (2020). Keanekaragaman Jenis Ikan Di Sepanjang Sungai Opak Propinsi Daerah Istimewa Yogyakarta, Indonesia. Biota: Jurnal Ilmiah IlmuIlmu Hayati, 5(2), 81-91. 